\title{
Synthesis, Characterization, Antibacterial, and Antifungal Activities of Cobalt(II), Nickel(II) and Copper(II) Complexes with 3-thioacetyl-2-amino-1,4-naphthoquinone and 2-benzoyl-3-amino-1,4-naphthoquinone Ligands
}

\author{
Fatma S. M. Hassan ${ }^{*}{ }^{*}$, Mahmoud Fayez ${ }^{2}$, Nadia Abdalla1 \\ ${ }^{1}$ Chemistry Department, Faculty of Science, Aswan University, Aswan, Egypt \\ ${ }^{2}$ Luxor Company for Water and Wastewater, Luxor, Egypt \\ Email: ^fatma_smhh@yahoo.com
}

How to cite this paper: Hassan, F.S.M., Fayez, M., and Abdalla, N. (2020) Synthesis, Characterization, Antibacterial, and Antifungal Activities of Cobalt(II), Nickel(II) and Copper(II) Complexes with 3-thioacetyl-2-amino-1,4-naphthoquinone and 2-benzoyl-3-amino-1,4-naphthoquinone Ligands. Open Journal of Inorganic Nonmetallic Materials, 10, 45-61.

https://doi.org/10.4236/ojinm.2020.104004

Received: October 1, 2020

Accepted: October 27, 2020

Published: October 30, 2020

Copyright $\odot 2020$ by author(s) and Scientific Research Publishing Inc. This work is licensed under the Creative Commons Attribution International License (CC BY 4.0).

http://creativecommons.org/licenses/by/4.0/ (c) (i) Open Access

\begin{abstract}
The aim of this work is to synthesize, characterize and evaluate the biological activity of 1,4-naphthoquinone derivatives ligands and their metal-Co(II), $\mathrm{Ni}$ (II) and $\mathrm{Cu}$ (II) chelates. Continuing our work with another derivatives of 1,4-naphthoquinone ligands, this work had been constructed for synthesis of new ligands derived from 1,4-naphthoquinone such as 3-thioacetyl-2-amino1,4-naphthoquinone and 2-benzoyl-3-amino-1,4-naphthoquinone $\left(\mathrm{L}^{1}-\mathrm{L}^{2}\right)$ which characterized on the basis of elemental analysis, electronic, IR, mass, ${ }^{1} \mathrm{H}-\mathrm{NMR}$ spectral data. The synthesized ligands have been carried out to achieve the coordination behavior towards bi-valent metal ions like cobalt, nickel and copper. The solid chelates of the different ligands were prepared and subjected to analytical techniques such as elemental analyses, spectroscopic techniques including mass, ${ }^{1} \mathrm{H}-\mathrm{NMR}$, and IR spectroscopy, and thermal analyses techniques. The chelates were found to have octahedral geometry. The biological activity of the prepared ligands and their binary metals complexes were also screened against different antifungal and antibacterial organisms.
\end{abstract}

\section{Keywords}

1,4-Naphthoquinone, Transition Metal Complexes, Antibacterial Activity, Antifungal Activity 


\section{Introduction}

Naphthoquinones are widely distributed in plants, fungi, and some animals. Their biological activities have been studied including their effects on prokaryotic and eukaryotic cells, [1]. Naphthoquinones are naturally occurring in plant origin that has antibacterial effects on several species of both aerobic and anaerobic organisms, and toxins derived from naphthazarin [2]. (5,8-dihydroxy-1,4naphthoquinone) are produced by attack plants, other fungi and bacteria [3]. The antimicrobial activity of the natural naphthoquinone products alkannin and their derivatives has been investigated, in general, they are active against Gram-positive bacteria such as Staphylococcus aureus, Enterococcus faecium, and Baciilus subtilis, but they are inactive against Gram-negative bacteria [4].

Antibacterial activity has been described for isoxazolylnaphtho-quinones and some hydroxyquinones and their metal complexes [5] [6]. The development of new antimicrobial agents is a research area of the utmost importance. Antimicrobial resistance among key microbial pathogens continues to grow at an alarming rate worldwide. Resistance among strains of $\mathcal{S}$. aureus, Pseudomonas spp, Streptococcus spp and Enterobacteriaceae has been described [7] [8] [9]. The increased prevalence of antibiotic-resistant bacteria emerging from the extensive use of antibiotics may render the current antimicrobial agents insufficient to control at least some bacterial infections. The challenge of synthesizing derivatives of natural antimicrobial naphthoquinones to improve their pharmaceutical properties has been accepted by several laboratories. Indeed, the synthesis and evaluation of antimicrobial activity of bioactive analogs of kigelinone, alkannin, [10] [11], have been reported. In the present study, we describe the antibacterial activity of a new series of 1,4-naphthoquinones. The metal chelates often caused decrease of biological activity. Cobalt complex of $\left(\mathrm{L}_{1}\right.$ and $\left.\mathrm{L}_{2}\right)$ was the most effective against Gram-positive bacteria, showing MIC values ranging from 375 to $1400 \mathrm{mg} / \mathrm{ml}$. Metal chelates may be useful tools for the understanding of the antimicrobial mechanism of 1,4-naphthoquinones on these bacteria [12].

\section{Experimental}

\subsection{Materials and Reagents}

Analytical grade chemical reagents were used. All chemicals used in this study are of the highest purity from commercial suppliers such as Merck; BDH and Aldrich they include 1,4-Naphthoquinone, Thioacetamide and Benzamide, $\mathrm{CoCl}_{2} \cdot 6 \mathrm{H}_{2} \mathrm{O}, \mathrm{NiCl}_{2} \cdot 6 \mathrm{H}_{2} \mathrm{O}$ and $\mathrm{CuCl}_{2} \cdot 2 \mathrm{H}_{2} \mathrm{O}$. The organic solvents such as an absolute ethanol and methanol, DMF and DMSO are purchased from Alpha Easer.

\subsection{Instrumentation}

Melting point apparatus (Gallen Kamp, Germany) was used to investigate the melting points. Elemental microanalysis of the separated solid chelates for $\mathrm{C}, \mathrm{H}$ and $\mathrm{N}$ were performed in the Micro analytical Center, Cairo University, using 
CHNS-932 (LECO) Vario Elemental analyzers. Infrared spectra were recorded on Perkin-Elmer FT-IR type 1650 spectrophotometer in wave number region $4000-40 \mathrm{~cm}^{-1}$. The spectra were recorded as $\mathrm{KBr}$ pellets. The ${ }^{1} \mathrm{H}$ NMR spectra were recorded using $300 \mathrm{MHz}$ Varian-Oxford Mercury. The deuterated solvent used was dimethylsulphoxide (DMSO- $\mathrm{d}_{6}$ ) and the spectra extended from 0 to 15 ppm. The electron impact (EI) mass spectra (MS) at $70 \mathrm{eV}$ of the tested compounds has been done using MS-5988 GS-MS Hewlett-Packard instrument. TGA was carried out in dynamic nitrogen atmosphere $\left(10 \mathrm{~mL} \cdot \mathrm{min}^{-1}\right)$ with a heating rate of $10^{\circ} \mathrm{C} \mathrm{min}^{-1}$ using DTG-50 $\mathrm{H}$ Shimadzu simultaneous. The molar conductance of solid chelates in DMF was measured using WPA CM35 Conductivity meter fitted with platinized platinum electrodes. The antibacterial and antifungal activities were evaluated at the Microbiological laboratory, Micro analytical center, Cairo University, Egypt.

\subsection{Methods}

\subsubsection{Synthesis of Free Ligands}

1,4-Naphthoquinone (2 g, $0.0126 \mathrm{~mol})$ mixed with an equivalent amount $(0.95 \mathrm{~g}$ and $0.53 \mathrm{~g}, 0.0126 \mathrm{~mol}$ ) of Thioacetamide and Benzamide respectively, then the mixture was added to an aqueous solution of sodium hydroxide and left for two hours on water bath to be fused. The crude product was recrystallized from ethanol and dried under vacuum over $\mathrm{P}_{2} \mathrm{O}_{5}$. The yield was $90 \%$. The melting point was measured and listed in Table 1 . The procedure cited in respective reference [13] [14].

\subsubsection{Preparation of Metal Complexes}

The metal complexes were prepared by dissolving (1.088 $\mathrm{g}$ and $1.385 \mathrm{~g}, 0.005$

Table 1. Analytical and physical properties of 1,4-naphthoquinone complexes.

\begin{tabular}{|c|c|c|c|c|c|c|c|c|}
\hline \multirow{2}{*}{ Compound (Molecular formula) } & \multirow{2}{*}{ Color } & \multirow{2}{*}{ m.p. ${ }^{\circ} \mathrm{C}$} & \multicolumn{3}{|c|}{ \% Found (Calcd) } & \multirow{2}{*}{ eff $\mu$} & \multirow{2}{*}{${ }^{1} \Omega \cdot \mathrm{mol}^{-1} \cdot \mathrm{cm}^{2}$} & \multirow{2}{*}{$\begin{array}{c}\text { Formula } \\
\text { weight }\end{array}$} \\
\hline & & & $\mathrm{C}$ & $\mathrm{H}$ & $\mathrm{N}$ & & & \\
\hline $\mathrm{L}^{1}\left[\mathrm{C}_{12} \mathrm{H}_{9} \mathrm{NSO}_{2}\right]$ & Brown & 241 & $\begin{array}{c}62.28 \\
(62.32)\end{array}$ & $\begin{array}{c}3.87 \\
(3.92)\end{array}$ & $\begin{array}{c}6.02 \\
(6.05)\end{array}$ & - & - & 231.27 \\
\hline$\left[\mathrm{CoC}_{12} \mathrm{H}_{9} \mathrm{NSO}_{2}\left(\mathrm{H}_{2} \mathrm{O}\right)_{2} \mathrm{Cl}_{2}\right] \cdot 4 \mathrm{H}_{2} \mathrm{O}$ & $\begin{array}{l}\text { Brown } \\
\text { reddish }\end{array}$ & 327 & $\begin{array}{c}30.64 \\
(30.71)\end{array}$ & $\begin{array}{c}4.47 \\
(4.51)\end{array}$ & $\begin{array}{c}2.94 \\
(2.98)\end{array}$ & 5.2 & 7.31 & 469.20 \\
\hline$\left[\mathrm{NiC}_{12} \mathrm{H}_{9} \mathrm{NSO}_{2}\left(\mathrm{H}_{2} \mathrm{O}\right)_{2} \mathrm{Cl}_{2}\right] \cdot 4 \mathrm{H}_{2} \mathrm{O}$ & $\begin{array}{l}\text { Brown } \\
\text { reddish }\end{array}$ & 371 & $\begin{array}{c}30.67 \\
(30.73)\end{array}$ & $\begin{array}{c}4.44 \\
(4.51)\end{array}$ & $\begin{array}{c}2.92 \\
(2.98)\end{array}$ & - & 8.60 & 468.96 \\
\hline$\left[\mathrm{CuC}_{12} \mathrm{H}_{9} \mathrm{NSO}_{2}\left(\mathrm{H}_{2} \mathrm{O}\right)_{2} \mathrm{Cl}_{2}\right]$ & $\begin{array}{l}\text { Brown } \\
\text { reddish }\end{array}$ & 336 & $\begin{array}{c}35.81 \\
(35.87)\end{array}$ & $\begin{array}{c}3.21 \\
(3.26)\end{array}$ & $\begin{array}{c}3.42 \\
(3.48)\end{array}$ & 3.4 & 5.46 & 401.75 \\
\hline $\mathrm{L}^{2}\left[\mathrm{C}_{17} \mathrm{H}_{11} \mathrm{NO}_{3}\right]$ & Brown & 251 & $\begin{array}{c}73.58 \\
(73.63)\end{array}$ & $\begin{array}{c}3.92 \\
(3.99)\end{array}$ & $\begin{array}{c}4.99 \\
(5.05)\end{array}$ & - & - & 277.27 \\
\hline$\left[\mathrm{Co} \mathrm{C}_{17} \mathrm{H}_{11} \mathrm{NO}_{3}\left(\mathrm{H}_{2} \mathrm{O}\right)_{2} \mathrm{Cl}_{2}\right] \cdot 4 \mathrm{H}_{2} \mathrm{O}$ & $\begin{array}{l}\text { Brown } \\
\text { reddish }\end{array}$ & 332 & $\begin{array}{c}38.58 \\
(39.63)\end{array}$ & $\begin{array}{c}4.45 \\
(4.49)\end{array}$ & $\begin{array}{c}2.66 \\
(2.71)\end{array}$ & & 8.86 & 515.20 \\
\hline$\left[\mathrm{Ni} \mathrm{C}_{17} \mathrm{H}_{11} \mathrm{NO}_{3}\left(\mathrm{H}_{2} \mathrm{O}\right)_{2} \mathrm{Cl}_{2}\right] \cdot 4 \mathrm{H}_{2} \mathrm{O}$ & $\begin{array}{l}\text { Brown } \\
\text { reddish }\end{array}$ & 382 & $\begin{array}{c}39.59 \\
(39.64)\end{array}$ & $\begin{array}{c}4.44 \\
(4.50)\end{array}$ & $\begin{array}{c}2.66 \\
(2.71)\end{array}$ & 3.27 & 9.89 & 514.96 \\
\hline$\left[\mathrm{CuC}_{17} \mathrm{H}_{11} \mathrm{NO}_{3}\left(\mathrm{H}_{2} \mathrm{O}\right)_{2} \mathrm{Cl}_{2}\right]$ & Brown & 346 & $\begin{array}{c}45.54 \\
(45.60)\end{array}$ & $\begin{array}{c}3.33 \\
(3.37)\end{array}$ & $\begin{array}{c}3.08 \\
(3.12)\end{array}$ & - & 5.78 & 447.75 \\
\hline
\end{tabular}


mol) of ligand $\left(\mathrm{L}^{1}-\mathrm{L}^{2}\right)$ respectively in hot ethanol $(50 \mathrm{ml})$ and added drop wisely with stirring to a stoichiometric amount of $1: 1(\mathrm{M}: \mathrm{L})$ molar ratio to $(1.189 \mathrm{~g}$, $1.888 \mathrm{~g}$, and $0.852 \mathrm{~g}, 0.005 \mathrm{~mol}$ ) of $\mathrm{CoCl}_{2} \cdot 6 \mathrm{H}_{2} \mathrm{O}, \mathrm{NiCl}_{2} \cdot 6 \mathrm{H}_{2} \mathrm{O}$ and $\mathrm{CuCl}_{2} \cdot 2 \mathrm{H}_{2} \mathrm{O}$ respectively. The reaction mixture was refluxed for $40 \mathrm{~min}$ and left overnight. The isolated solid complexes were filtered off, washed with distilled water until the solution became colorless and washed with $10 \mathrm{ml}$ hot ethanol-water mixture (1:1) to remove any traces of the unreacted materials. The solid complexes were dried at $70^{\circ} \mathrm{C}$ for several hours kept in desiccator containing dry $\mathrm{P}_{2} \mathrm{O}_{5}$. Analytical data were listed in Table 1.

\subsubsection{Biological Activity}

Modified Kirby-Bauer disc diffusion method [15], has been used to determine the antimicrobial activity of the tested samples [16]. Examined $100 \mu \mathrm{l}$ of the tested bacteria or fungi, it has been found that it was developed in $10 \mathrm{ml}$ of fresh media until they reached a count of approximately 108 cells $/ \mathrm{ml}$ for bacteria and 105 cells/ml for fungi. $100 \mu \mathrm{l}$ of microbial suspension was spread onto agar plates corresponding to broth in which they were maintained. Isolated colonies of each organism that might be playing a pathogenic role should be selected from primary agar plates and tested for susceptibility by disc diffusion method of the many media available; NCCLS recommends Mueller-Hinton agar due to it results in good batch-to-batch reproducibility. Disc diffusion method for filamentous fungi tested by using approved standard method (M38-A) developed. For evaluating the susceptibilities of filamentous fungi to antifungal agent, Disc diffusion method for yeast developed by National Committee for Clinical Laboratory Standards using approved standard method (M44-P). Plates inoculated with filamentous fungi as Asprgillus flavus at $25^{\circ} \mathrm{C}$ for 48 hours; Gram (+) bacteria as Staphylococcus aureus, Gram(-) bacteria as Escherichia coli, they were incubated at $35^{\circ} \mathrm{C}-37^{\circ} \mathrm{C}$ for $24-28$ hours and yeast as Candida albicans incubated at $30^{\circ} \mathrm{C}$ for $24-28$ hours, then the diameters of the inhibition zones were measured in millimeters with slipping calipers of the National Committee for clinical Laboratory Standards [17], have been used standard discs of tetracycline (antibacterial agent), and amphotericin B (antifungal agent) served as positive controls for antimicrobial activity but filter discs impregnated with $10 \mu \mathrm{l}$ of solvent (distilled water, chloroform, DMSO) were used as a negative control. The agar used is Mueller-Hinton agar that is rigorously tested for composition and $\mathrm{pH}$. Further the depth of the agar in the plate is a factor to be considered in the disc diffusion method. This method is well documented and standard zones of inhibition have been determined for susceptible and resistant values. Blank paper discs (Schleicher and Schuell, Spain) with a diameter of $8.0 \mathrm{~mm}$ were impregnated with $10 \mu \mathrm{l}$ of tested concentration of the stock solutions. When a filter paper disc impregnated with a tested chemical is placed on agar, the chemical will diffuse from the disc into the agar. This diffusion will place the chemical in the agar only around the disc. The solubility of the chemical and its molecular size will determine the size of the area of chemical infiltration around the disc. If 
an organism is placed on the agar, it will not grow in the area around the disc if it is susceptible to the chemical. This area of no growth around the disc is known as zone of inhibition or clear zone. For the disc diffusion, the zone diameters were measured [18], found that, agar-based methods such test and disc diffusion can be good alternatives because they are simpler and faster than broth-based methods.

\section{Results and Discussion}

\subsection{Elemental Analysis and Physical Properties}

The results of elemental analyses and physical properties of the free ligands and its metal chelates shown in Table 1 are in good agreement with those required by proposed formulae. The isolated solid complexes are stable at room temperature, partly soluble in polar organic solvents, but completely soluble in polar aprotic solvents such as DMF and DMSO. Based on the above mentioned results, it can propose the general structural formulae of 1:1 (M:L) complexes (Figure 1, Figure 2).

\subsection{Molar Conductivity Measurements}

The metal chelates were dissolved in DMF at $25^{\circ} \mathrm{C} \pm 2^{\circ} \mathrm{C}$ and the molar conductivities of $5 \times 10^{-4} \mathrm{M}$ of their solutions were measured by recommended procedure [19]. The obtained molar conductance values are listed in Table 1. The molar conductivity value of $\mathrm{Co}(\mathrm{II}), \mathrm{Ni}(\mathrm{II})$ and $\mathrm{Cu}(\mathrm{II})$ chelates of free ligands ( $\mathrm{L}^{1}$ $\left.\mathrm{L}^{2}\right)$ were found to be 5.46 up to $9.89 \Omega^{-1} \cdot \mathrm{mol}^{-1} \cdot \mathrm{cm}^{2}$. The chelates are nonionic in nature and they are considered as non-electrolytes.

\subsection{FT-IR Spectroscopy}

\subsubsection{FT-IR of 3-thioacetyl-2-amino-1,4-naphthoquinone ( $\left.\mathrm{L}^{1}\right)$ and Its Metal Chelates}

The main FT-IR bands of 3-thioacetyl-2-amino-1,4-naphthoquinone $\left(\mathrm{L}^{1}\right)$ and its metal chelates are presented in Table 2, Figure 3.

The vibration spectra of ligand Cexhibit a very broad band at $3436 \mathrm{~cm}^{-1}$ assigned to the $v\left(\mathrm{NH}_{2}\right)$ stretching vibration of $\left(\mathrm{C}_{2}-\mathrm{NH}_{2}\right)$ of the naphthoquinone. The stretching band at $1563 \mathrm{~cm}^{-1}$ is attributed to $v(\mathrm{C}-\mathrm{N})$ ring stretching vibration. The stretching band at $1259 \mathrm{~cm}^{-1}$ assigned to the $v(\mathrm{C}=\mathrm{S})$ which in good agreement with the structure proposed of the ligand [14]. The FT-IR spectrum of 3-thioacetyl-2-amino-1,4 naphthoquinone ( $\left.\mathrm{L}^{1}\right)$ metal chelates exhibits different

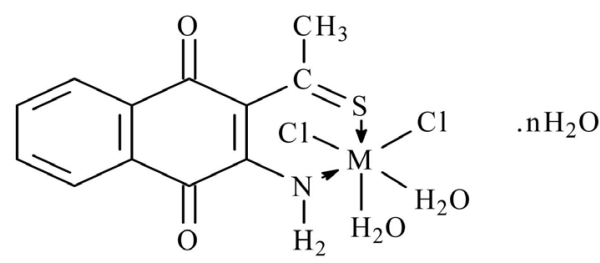

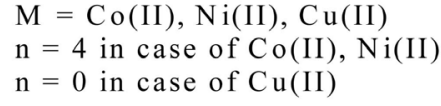

Figure 1. The proposed structure of the prepared metal complexes with 3-thioacetyl-2amino-1,4-naphthoquinon $\left(\mathrm{L}^{1}\right)$. 


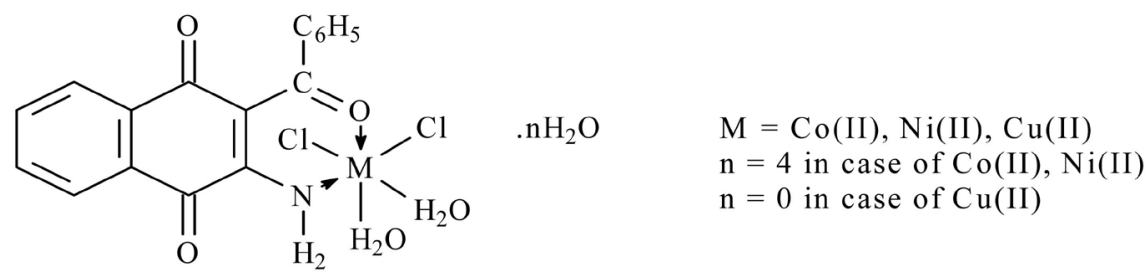

Figure 2. The proposed structure of the prepared metal complexes with 2-benzoyl-3amino-1,4-naphthoquinon $\left(\mathrm{L}^{2}\right)$.

Table 2. Infrared spectral data of free ligand $\left(\mathrm{L}^{1}-\mathrm{L}^{2}\right)$ and their metal chelates.

\begin{tabular}{|c|c|c|c|c|c|c|c|}
\hline Compound & $\begin{array}{c}v \\
\left(\mathrm{H}_{2} \mathrm{O}\right)\end{array}$ & $\begin{array}{c}v \\
\left(\mathrm{NH}_{2}\right)\end{array}$ & $\begin{array}{c}v \\
(\mathrm{C}=\mathrm{O})\end{array}$ & $\begin{array}{c}v \\
(\mathrm{C}-\mathrm{N})\end{array}$ & $\begin{array}{c}v \\
(\mathrm{C}=\mathrm{S})\end{array}$ & $\begin{array}{c}v \\
(M-O)\end{array}$ & $\begin{array}{c}v \\
(\mathrm{M}-\mathrm{N})\end{array}$ \\
\hline $\mathrm{L}^{1}$ & - & $3436 \mathrm{~b}$ & - & $1563 \mathrm{~s}$ & $1259 \mathrm{~s}$ & - & - \\
\hline $\mathrm{L}^{1}+\mathrm{Co}(\mathrm{II})$ & $\begin{array}{c}3547 \mathrm{w} \\
839 \mathrm{~s}\end{array}$ & $3400 \mathrm{~b}$ & - & $1598 \mathrm{~s}$ & $1229 w$ & 590 & 472 \\
\hline $\mathrm{L}^{1}+\mathrm{Ni}(\mathrm{II})$ & $\begin{array}{c}3527 \mathrm{w} \\
824 \mathrm{~s}\end{array}$ & $3392 b$ & - & $1576 \mathrm{~s}$ & $1225 w$ & 589 & 470 \\
\hline $\mathrm{L}^{1}+\mathrm{Cu}(\mathrm{II})$ & $\begin{array}{c}3538 w \\
896 \mathrm{~s}\end{array}$ & $3351 b$ & - & $1587 \mathrm{~s}$ & $1227 w$ & 593 & 474 \\
\hline $\mathrm{L}^{2}$ & - & $3424 b$ & $1663 \mathrm{~s}$ & $1553 \mathrm{~s}$ & - & - & - \\
\hline $\mathrm{L}^{2}+\mathrm{Co}(\mathrm{II})$ & $\begin{array}{c}3542 \mathrm{w} \\
824 \mathrm{~s}\end{array}$ & $3412 b$ & $1619 \mathrm{~s}$ & $1570 \mathrm{~s}$ & - & 588 & 470 \\
\hline $\mathrm{L}^{2}+\mathrm{Ni}(\mathrm{II})$ & $\begin{array}{c}3525 \mathrm{w} \\
839 \mathrm{~s}\end{array}$ & $3369 b$ & $1653 w$ & $1579 \mathrm{~s}$ & - & 584 & 480 \\
\hline $\mathrm{L}^{2}+\mathrm{Cu}(\mathrm{II})$ & $\begin{array}{c}3538 w \\
850 \mathrm{~s}\end{array}$ & $3352 b$ & $1650 w$ & $1580 \mathrm{~s}$ & - & 592 & 450 \\
\hline
\end{tabular}

bands. A new band appeared at 3547, 3527 and $3538 \mathrm{~cm}^{-1}$ for $\mathrm{Co}(\mathrm{II}), \mathrm{Ni}(\mathrm{II})$ and $\mathrm{Cu}(\mathrm{II})$ respectively, that suggests water molecules in the prepared complexes are loosely coordinated or exist as molecules of crystallization. The lower shift of $v$ $\left(\mathrm{NH}_{2}\right)$ band in the region at 3400,3392 and $3351 \mathrm{~cm}^{-1}$ for $\mathrm{Co}(\mathrm{II}), \mathrm{Ni}(\mathrm{II})$ and $\mathrm{Cu}$ (II) complexes respectively support the contribution of $\mathrm{N}$-atom of $\mathrm{NH}_{2}$ group in complex formation. The observed stretching vibration band $v(\mathrm{C}=\mathrm{S})$, at 1259 $\mathrm{cm}^{-1}$ of the ligand $\mathrm{L}^{1}$ show lower shift stretching vibration on complexation to $\mathrm{Co}(\mathrm{II}), \mathrm{Ni}(\mathrm{II})$ and $\mathrm{Cu}(\mathrm{II})$ at 1229,1225 and $1227 \mathrm{~cm}^{-1}$ respectively which supports the involvement of Sulphur atom of $(\mathrm{C}=\mathrm{S})$ group in the chelation. Also, on complexation the $v(\mathrm{C}-\mathrm{N})$ stretching vibration at 1598,1576 and $1587 \mathrm{~cm}^{-1}$ for $\mathrm{Co}(\mathrm{II}), \mathrm{Ni}(\mathrm{II})$ and $\mathrm{Cu}(\mathrm{II})$ respectively show red shift in these bands, which may be due to increase of bond order of carbon to the nitrogen link following the coordination of the imine nitrogen atom to metal ions. The stretching band of the coordinated water molecules $v\left(\mathrm{H}_{2} \mathrm{O}\right)$ was observed at 839,824 and $896 \mathrm{~cm}^{-1}$ for $\mathrm{Co}(\mathrm{II}), \mathrm{Ni}(\mathrm{II})$ and $\mathrm{Cu}(\mathrm{II})$ respectively. The new bands observed at 590, 589 and $593 \mathrm{~cm}^{-1}$ in all complexes under study may be assigned to $v(\mathrm{M}-\mathrm{O})$ and at 472,470 and $474 \mathrm{~cm}^{-1}$ assigned to $v(\mathrm{M}-\mathrm{N})$. 


\subsubsection{FT-IR of 2-benzoyl-3-Amino-1,4-naphthoquinone $\left(L^{2}\right)$ and Its Metal Chelates}

The main FT-IR bands of 2-benzoyl-3-amino-1,4-naphthoquinone $\left(\mathrm{L}^{2}\right)$ and its metal chelates are presented in Table 2.

The vibration spectra of ligand $\mathrm{L}^{2}$ exhibit a very broad band at $3424 \mathrm{~cm}^{-1}$ assigned to the $v\left(\mathrm{NH}_{2}\right)$ stretching vibration of $\left(\mathrm{C}_{2}-\mathrm{NH}_{2}\right)$ of the naphthoquinone. The stretching band at $1663 \mathrm{~cm}^{-1}$ could be assigned to the $v(\mathrm{C}=\mathrm{O})$. The stretching band at $1553 \mathrm{~cm}^{-1}$ may be attributed to $v(\mathrm{C}-\mathrm{N})$ ring stretching vibration. The vibration spectra of the formed complexes of $\mathrm{L}^{2}$, exhibit a broad band around 3542,3525 and $3538 \mathrm{~cm}^{-1}$ due to the $v(\mathrm{OH})$ stretching. The lower shift of $v\left(\mathrm{NH}_{2)}\right.$ band in the region at 3412, 3369 and $3352 \mathrm{~cm}^{-1}$ for $\mathrm{Co}(\mathrm{II}), \mathrm{Ni}(\mathrm{II})$ and $\mathrm{Cu}$ (II) complexes respectively support the contribution of $\mathrm{N}$-atom of $\mathrm{NH}_{2}$ group in complex formation. Also, the lower frequency shift of this band confirms our suggestion that $\mathrm{NH}_{2}$ is taking part in coordination. The observed low shift of $v$ $(\mathrm{C}=\mathrm{O}) 1663 \mathrm{~cm}^{-1}$ band of the ligand $\mathrm{L}^{2}$ on complexation to $\mathrm{Co}(\mathrm{II}), \mathrm{Ni}(\mathrm{II})$ and $\mathrm{Cu}(\mathrm{II})$ ions respectively at 1619,1653 and $1650 \mathrm{~cm}^{-1}$ which supports the involvement of oxygen atom of $(\mathrm{C}=\mathrm{O})$ group in the chelation. On the other hand, on complexation the $v(\mathrm{C}-\mathrm{N})$ stretching vibrations at 1570,1579 and $1580 \mathrm{~cm}^{-1}$ for $\mathrm{Co}(\mathrm{II}), \mathrm{Ni}(\mathrm{II})$ and $\mathrm{Cu}(\mathrm{II})$ ions respectively show red shift in these bands, which may be due to increase of bond order of carbon to the nitrogen link following the coordination of the imine nitrogen atom to metal ions [20]. The stretching band of the coordinated water molecules $v\left(\mathrm{H}_{2} \mathrm{O}\right)$ was observed at 824, 839 and $850 \mathrm{~cm}^{-1}$ for $\mathrm{Co}(\mathrm{II}), \mathrm{Ni}(\mathrm{II})$ and $\mathrm{Cu}(\mathrm{II})$ complexes respectively. The new bands observed at 588, 584 and 592 and in all complexes under study may be assigned to $v(\mathrm{M}-\mathrm{O})$ and at 470,480 and $450 \mathrm{~cm}^{-1}$ may be assigned to $v(\mathrm{M}-\mathrm{N})$.

\section{4. ${ }^{1} \mathrm{H}-\mathrm{NMR}$ Measurements}

\subsection{1. ${ }^{1} \mathrm{H}$-NMR of 3 -thioacetyl-2-amino-1,4-naphthoqunone $\left(\mathrm{L}^{1}\right)$ and Its Nickel Complex}

${ }^{1} \mathrm{H}$-NMR spectrum $300 \mathrm{MHz}$ of 3-thioacetyl-2-amino-1,4-naphthoqunone ( $\mathrm{L}^{1}$ ) shows several signals and the resulted data are tabulated in Table 3, Figure 4.

The ${ }^{1} \mathrm{H}$ NMR spectrum $\left(\mathrm{L}^{1}\right)$ shows a singlet signal at $\delta 2.5 \mathrm{ppm}$ of relative intensity $(\mathrm{s}, 3 \mathrm{H})$ may be attributed to $\mathrm{CH}_{3}$ protons, a multiplet at $\delta 7.2-7.5 \mathrm{ppm}$ of relative intensity $4 \mathrm{H}$, which may be assigned to four protons $(\mathrm{m}, 4 \mathrm{H})$ in quinone, $\mathrm{H}_{\text {arm }}$. The multiplet signal observed at $\delta 8 \mathrm{ppm}$ may be assigned to two protons of amino group $\left(\mathrm{m}, 2 \mathrm{H}, \mathrm{NH}_{2}\right)$ [21]. The comparison of the protons signals,

Table 3. ${ }^{1} \mathrm{H}-\mathrm{NMR}$ data for free ligands $\left(\mathrm{L}^{1}-\mathrm{L}^{2}\right)$ and their metal chelates.

\begin{tabular}{cccccc}
\hline Compound & $\delta \mathrm{CH}_{3}$ & $\delta \mathrm{CHO}$ & $\delta \mathrm{H}_{2} \mathrm{O}$ & $\delta(\mathrm{Ar}-\mathrm{H})$ & $\delta \mathrm{NH}_{2}$ \\
\hline $\mathrm{L}^{1}$ & 2.50 & ----- & ----- & $7.2-7.5$ & 8.0 \\
$\mathrm{~L}^{1}+\mathrm{Ni}(\mathrm{II})$ & 2.48 & ----- & 3.29 & $7.12-7.59$ & 7.89 \\
$\mathrm{~L}^{2}$ & ----- & $-\cdots--$ & $-\cdots--$ & $7.29-7.51$ & 7.9 \\
$\mathrm{~L}^{2}+\mathrm{Cu}(\mathrm{II})$ & ----- & ----- & 3.34 & $7.0-7.4$ & 7.82 \\
\hline
\end{tabular}


multiplets and the chemical shifts of $\mathrm{L}^{1}$ ligand with its corresponding nickel chelate $\left[\mathrm{NiC}_{12} \mathrm{O}_{2} \mathrm{H}_{9} \mathrm{NS} \mathrm{Cl}_{2}\left(\mathrm{H}_{2} \mathrm{O}\right)_{2}\right] \cdot 4 \mathrm{H}_{2} \mathrm{O}$ is investigated. It has been found that methyl protons of the free ligand are slightly shifted to $\delta 2.48 \mathrm{ppm}$. Also, the $\mathrm{NH}_{2}$ protons of the free ligands are slightly shifted to $\delta 7.89 \mathrm{ppm}$. This suggests that the metal ion coordination takes place through the nitrogen atom of $\mathrm{NH}_{2}$ group. The proton signal observed at $\delta 3.29 \mathrm{ppm}$, which may be assigned to the presence of water molecules is in agreements with the suggested formulae of metal chelates.

\subsection{2. ${ }^{1} \mathrm{H}$-NMR of 2-benzoyl-3-amino-1,4-naphthoqunone $\left(\mathrm{L}^{2}\right)$ and Its Copper Complex}

${ }^{1} \mathrm{H}$-NMR spectrum $300 \mathrm{MHz}$ of 2-benzoyl-3-amino-1,4-naphthoqunone ( $\left.\mathrm{L}^{2}\right)$ shows several signals and the resulted data are tabulated in Table 3.

The ${ }^{1} \mathrm{H}$ NMR spectrum $\left(\mathrm{L}^{2}\right)$ shows a singlet signal at $\delta 7.29-7.51 \mathrm{ppm}$, which may be assigned to four protons $(\mathrm{m}, 4 \mathrm{H})$ in quinone, $\mathrm{H}_{\text {arm }}$ and five protons $(\mathrm{m}$, $5 \mathrm{H}$ ) in phenyl group. The multiplet signal shown at $\delta 7.9 \mathrm{ppm}$ may be assigned to two protons of amino group $\left(\mathrm{m}, 2 \mathrm{H}, \mathrm{NH}_{2}\right)$ [22]. On comparing the investigated ${ }^{1} \mathrm{H}$-NMR signals of the copper chelate $\left[\mathrm{CuC}_{17} \mathrm{H}_{11} \mathrm{NO}_{3} \mathrm{Cl}_{2}\left(\mathrm{H}_{2} \mathrm{O}\right)_{2}\right]$ with those of the $\mathrm{L}^{2}$ ligand protons signals, multiplets and the chemical shifts. It has been found that the $\mathrm{NH}_{2}$ protons of the free ligands are slightly shifted to $\delta 7.82 \mathrm{ppm}$ this suggests that the metal ion coordination takes place through the nitrogen atom of $\mathrm{NH}_{2}$ group. The proton signal observed at $\delta 3.34 \mathrm{ppm}$, which may be assigned to the presence of water molecules is in agreements with the suggested formulae of metal chelates.

\subsection{Mass Spectroscopic Studies}

\subsubsection{Mass Spectra of 3-thioacetyl-2-amino-1,4-naphthoqunone $\left(L^{1}\right)$ and} Its Nickel Complex

The electron impact mass spectrum of $\left[\mathrm{Ni}\left(\mathrm{Cl}_{2} \mathrm{O}_{2} \mathrm{H}_{9} \mathrm{NS}\right) \mathrm{Cl}_{2}(\mathrm{H} 2 \mathrm{O})_{2}\right] \cdot 4 \mathrm{H}_{2} \mathrm{O}$ Figure 5 shows many fragment ions which consists of two principle pathways as shown in Scheme 1. The signal that appears at $\mathrm{m} / \mathrm{z}=468.95$ (mole mass $=468.96$ ) may be referred to the appearance of main general molecular weight of metal chelate which undergo two pathways of fragmentation. Pathway I shows a signal at $\mathrm{m} / \mathrm{z}$ $=324.07$ (mole mass $=328.39, \mathrm{RI}=15 \%$ ); which may be refer to the loss of five molecules of water, $\mathrm{CH}_{3}$ and $\mathrm{Cl}^{-}$ion, followed by the appearance of a signal at $\mathrm{m} / \mathrm{z}=271.55$ (mole mass $=274.93, \mathrm{RI}=15 \%$ ); which may be refer to the loss of one molecule of water and $\mathrm{Cl}^{-}$ion, followed by the appearance of a signal at $\mathrm{m} / \mathrm{z}=90.07$ (mole mass $=90.75, \mathrm{RI}=34 \%$ ) as rupture of $\mathrm{C}_{11} \mathrm{H}_{6} \mathrm{NO}_{2}$ (furo[2,3-b]quinolin-8-olate). Pathway II shows a fragment at $\mathrm{m} / \mathrm{z}=324.07$ (mole mass $=325.99, \mathrm{RI}=15 \%)$ may be assigned to the loss of four water molecules, $\mathrm{Cl}_{2}$ followed by the loss of $\mathrm{C}_{8} \mathrm{H}_{4} \mathrm{O}_{2}$ (benzocyclobutenedione) molecule and two water molecules leaving a fragment give a signal at $\mathrm{m} / \mathrm{z}=157.57$ (mole mass $=$ $157.84, \mathrm{RI}=34 \%$ ). A signal appeared at $\mathrm{m} / \mathrm{z}=90.05$ (mole mass $=90.75, \mathrm{RI}=$ $34 \%$ ) as a rupture of $\mathrm{C}_{4} \mathrm{H}_{5} \mathrm{~N}$ (pyrrole). 


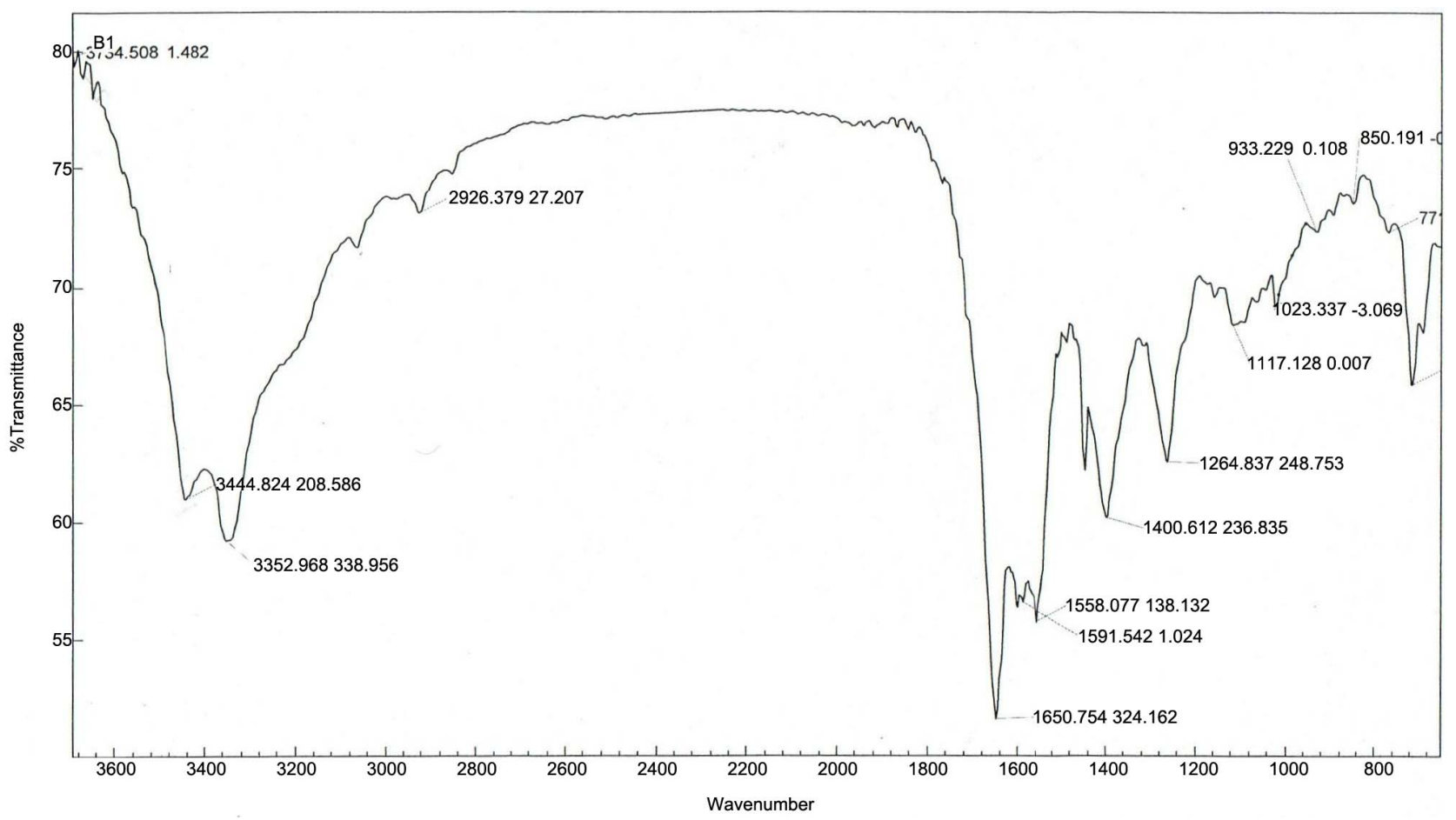

Figure 3. FT-IR of $\left[\mathrm{Cu} \mathrm{L}^{2} \mathrm{Cl}_{2}\left(\mathrm{H}_{2} \mathrm{O}\right)_{2}\right]$.

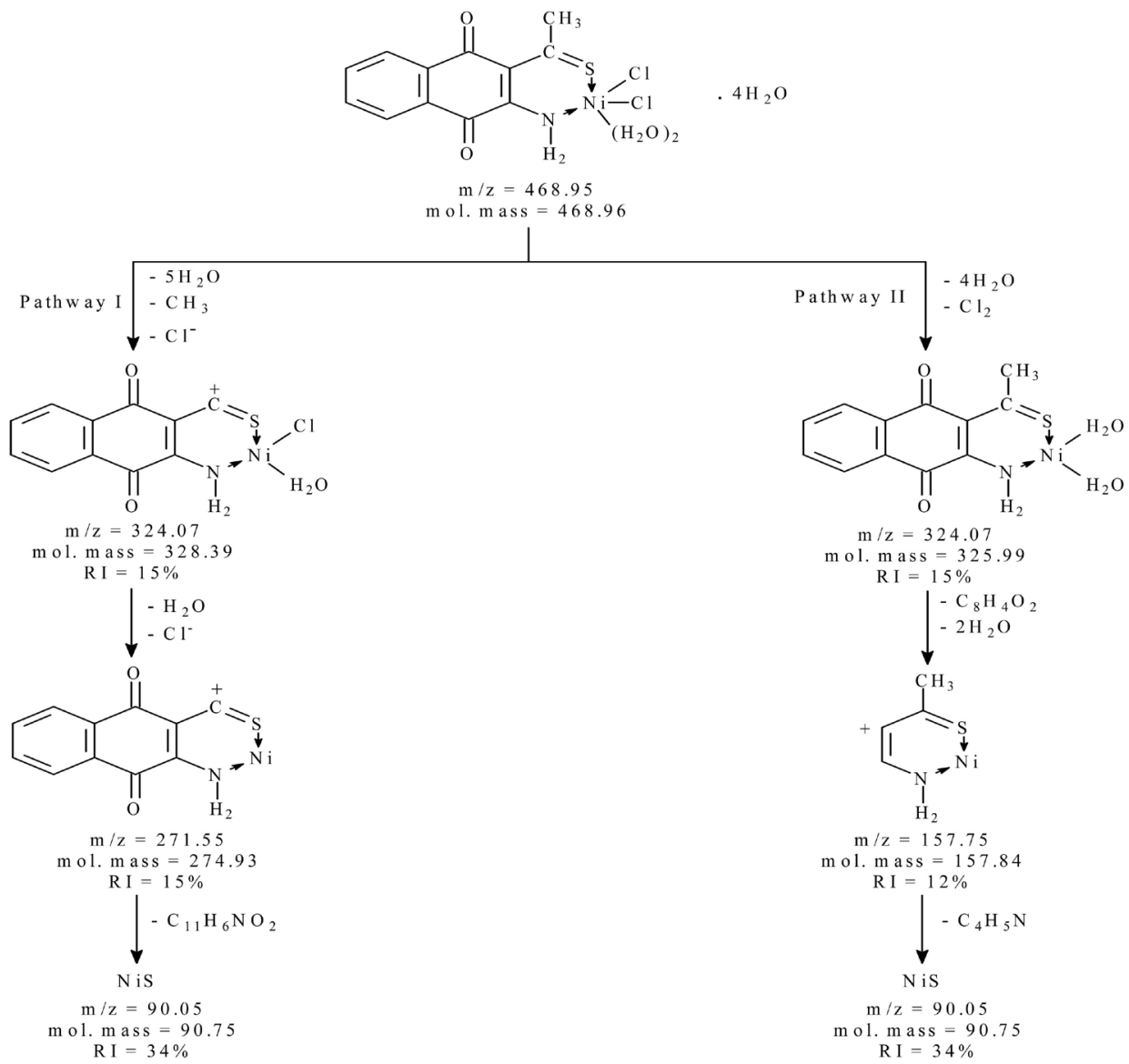

Scheme 1. The mass fragmentation pathways of $\left[\mathrm{Ni} \mathrm{L} \mathrm{L}^{1} \mathrm{Cl}_{2}\left(\mathrm{H}_{2} \mathrm{O}\right)_{2}\right] \cdot 4 \mathrm{H}_{2} \mathrm{O}$. 
3.5.2. Mass Spectra of 2-benzoyl-3-amino-1,4-naphthoqunone $\left(\mathrm{L}^{2}\right)$ and Its Cobalt Complex

The electron impact mass spectrum of $\left[\mathrm{CoC}_{17} \mathrm{H}_{11} \mathrm{NO}_{3} \mathrm{Cl}_{2}\left(\mathrm{H}_{2} \mathrm{O}\right)_{2}\right]$ Figure 6 shows many fragment ions which consists of two principle pathways as shown in Scheme 2. The signal that appears at $\mathrm{m} / \mathrm{z}=514.80$ (mole mass $=515.20$ ) may be referred to the appearance of main general molecular weight of metal chelate which undergo two pathways of fragmentation. Pathway I stated that; the main metal chelates lose six molecules of water and $\mathrm{C}_{6} \mathrm{H}_{5}$ (phenyl radical) leaving a fragment at $\mathrm{m} / \mathrm{z}=327.07$ (mole mass $=330.01, \mathrm{RI}=12 \%$ ) followed by the appearance of a signal at $\mathrm{m} / \mathrm{z}=127.89$ (mole mass $=126.98, \mathrm{RI}=4 \%$ ); which may be refer to the loss of $\mathrm{C}_{8} \mathrm{H}_{4} \mathrm{O}_{2}$ (benzocyclobutenedione) and $\mathrm{Cl}_{2}$. followed by the appearance of a signal at $\mathrm{m} / \mathrm{z}=76.95$ (mole mass $=74.93, \mathrm{RI}=55 \%$ ) as rupture of $\mathrm{C}_{3} \mathrm{H}_{2} \mathrm{~N}^{+}$(1-Cyanoacetylenecation). Pathway II shows a fragment at $\mathrm{m} / \mathrm{z}=$ 311.07 (mole mass $=313.15, \mathrm{RI}=80 \%$ ); which may be refer to the loss of three molecules of water, $\mathrm{Cl}_{2}$ and $\mathrm{C}_{6} \mathrm{H}_{5}$ (phenyl radical), followed by the appearance of a signal at $\mathrm{m} / \mathrm{z}=76.95$ (mole mass $=74.93, \mathrm{RI}=55 \%$ ) as rupture of $\mathrm{C}_{11} \mathrm{H}_{6} \mathrm{NO}_{2}$ (furo[2,3-b]quinolin-8olate) (Figure 5, Figure 6).

\subsection{Thermogravimetric Analyses (TGA)}

The TGA thermal analyses data of the synthesized metal chelates are tabulated in Table 4.

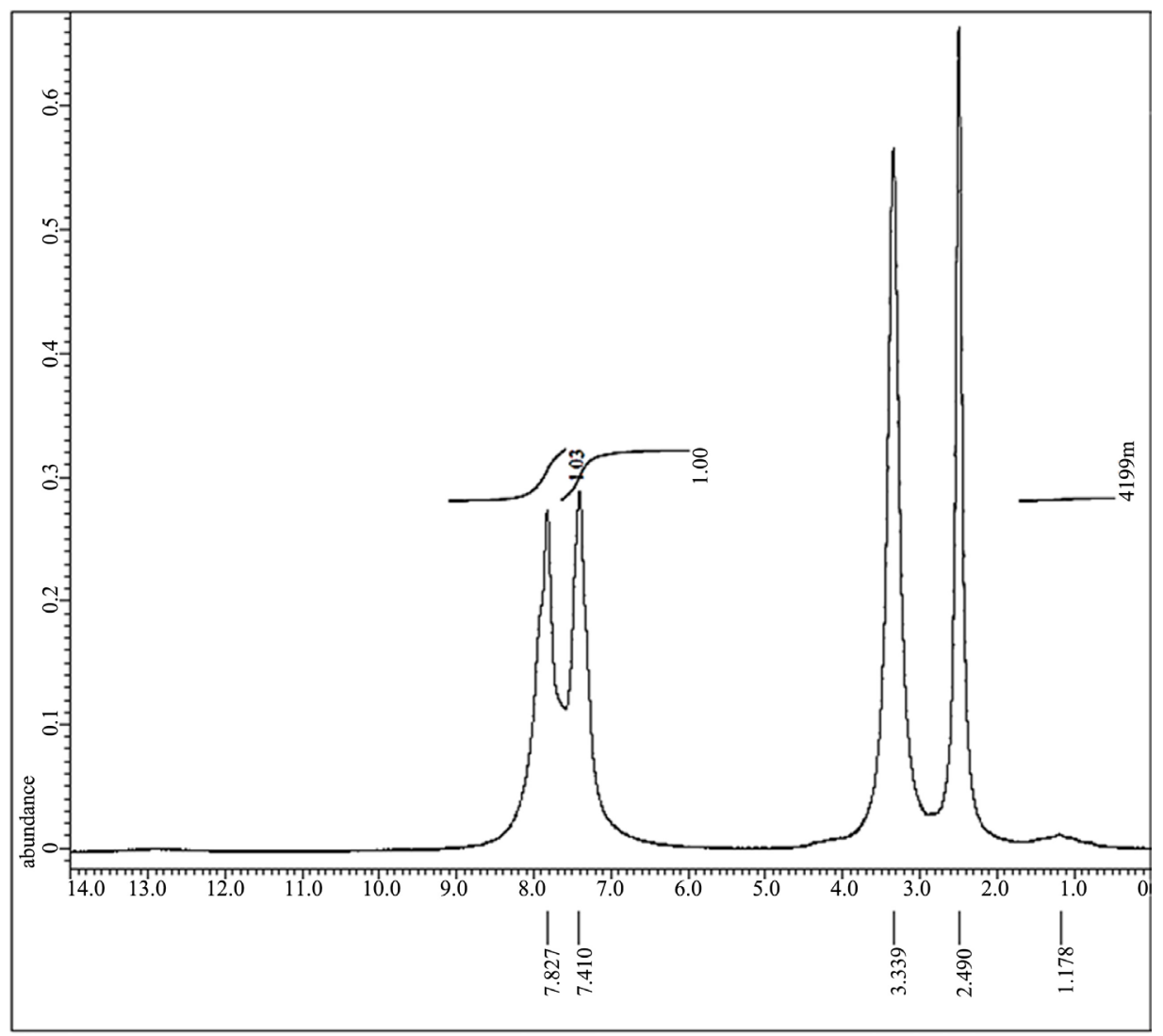

Figure 4. ${ }^{1} \mathrm{H}-\mathrm{NMR}$ spectrum of $\left[\mathrm{Cu} \mathrm{L}^{2} \mathrm{Cl}_{2}\left(\mathrm{H}_{2} \mathrm{O}\right)_{2}\right]$. 


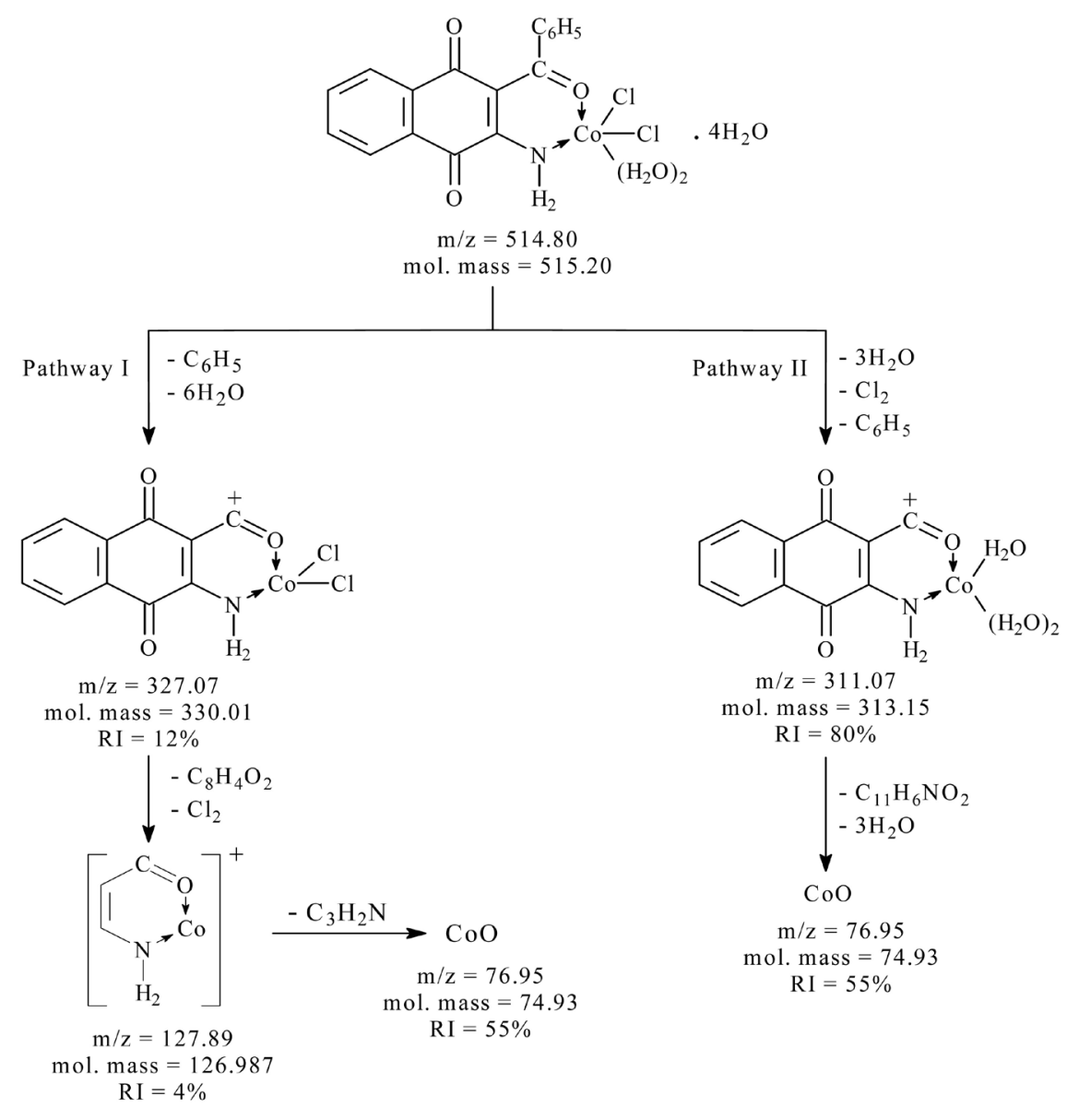

Scheme 2. The mass fragmentation pathways of $\left[\mathrm{Co}^{2} \mathrm{Cl}_{2}\left(\mathrm{H}_{2} \mathrm{O}\right)_{2}\right] \cdot 4 \mathrm{H}_{2} \mathrm{O}$.

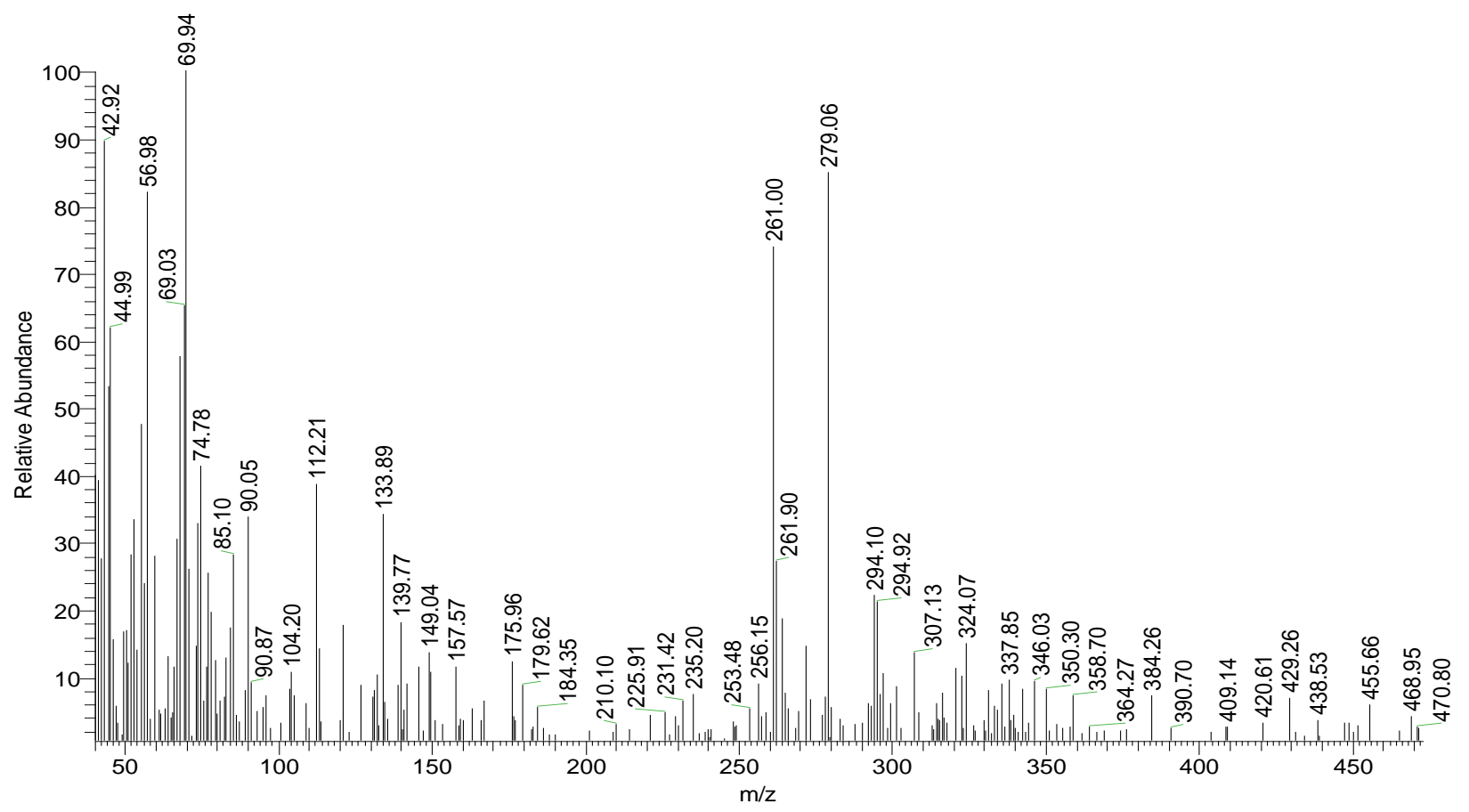

Figure 5. Mass Spectrum of $\left[\mathrm{Ni} \mathrm{L}^{1} \mathrm{Cl}_{2}\left(\mathrm{H}_{2} \mathrm{O}\right)_{2}\right] \cdot 4 \mathrm{H}_{2} \mathrm{O}$. 


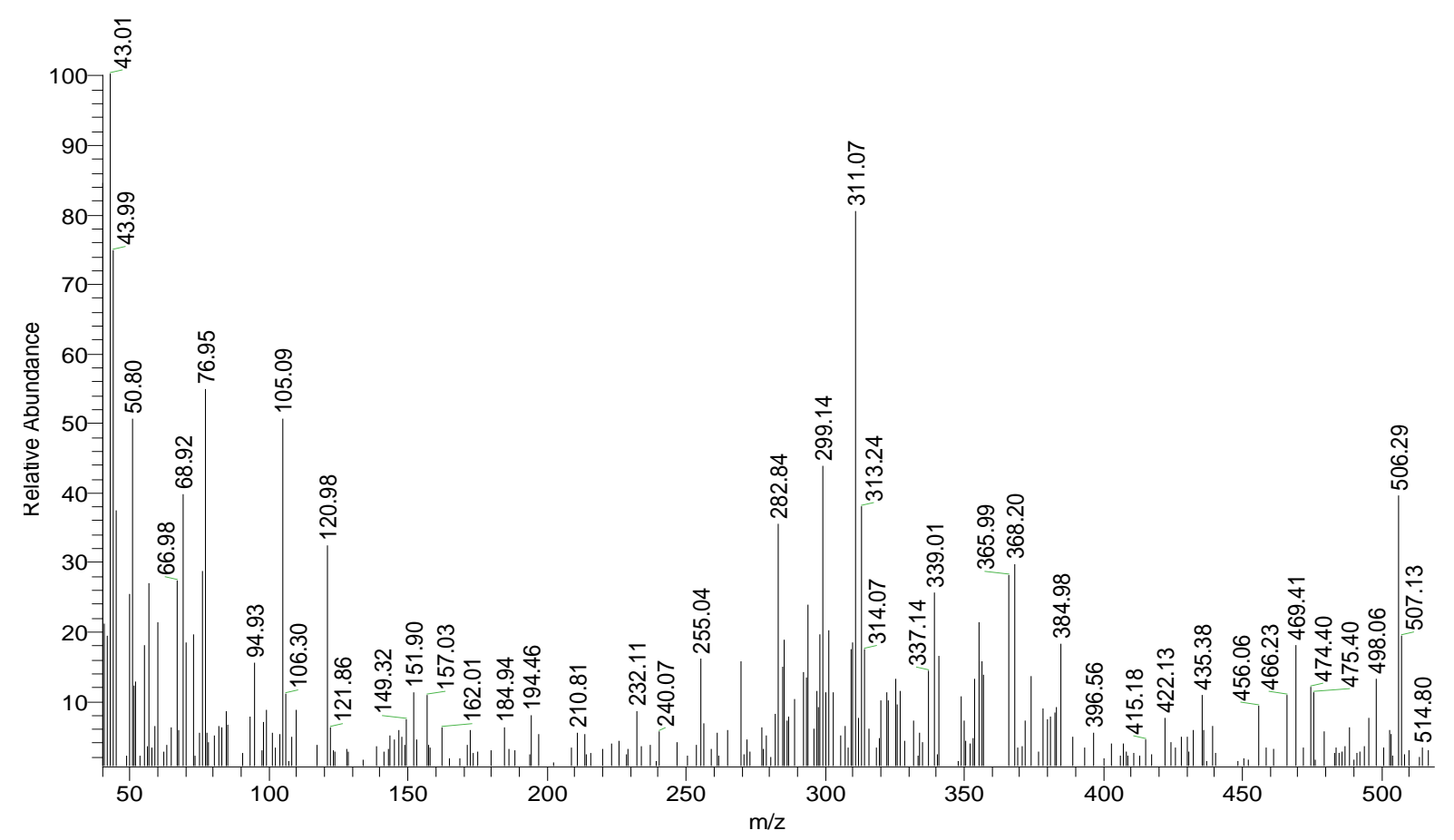

Figure 6. Mass Spectrum of $\left[\mathrm{Co} \mathrm{L}^{2} \mathrm{Cl}_{2}\left(\mathrm{H}_{2} \mathrm{O}\right)_{2}\right] \cdot 4 \mathrm{H}_{2} \mathrm{O}$.

Table 4. Thermoanalytical analyses data for newly synthesized chelates of ligands $\left(\mathrm{L}^{1}-\mathrm{L}^{2}\right)$.

\begin{tabular}{cccc}
\hline Compound & Temp range $^{\circ} \mathrm{C}$ \% Mass loss found (calcd.) & Assignment \\
\hline & $50-250$ & $16.36(15.36)$ & - Loss of $4 \mathrm{H}_{2} \mathrm{O}$ \\
{$\left[\mathrm{Ni} \mathrm{L}^{1} \mathrm{Cl}_{2}\left(\mathrm{H}_{2} \mathrm{O}\right)_{2}\right] \cdot 4 \mathrm{H}_{2} \mathrm{O}$} & $250-450$ & $12.58(10.88)$ & - Loss of $2 \mathrm{H}_{2} \mathrm{O}, \mathrm{CH}_{3}$ \\
& $450-670$ & $18.92(18.53)$ & - Loss of $\mathrm{NH}_{2}, \mathrm{Cl}_{2}$ \\
& $670-980$ & $32.20(35.85)$ & - Loss of $\mathrm{C}_{11} \mathrm{H}_{4} \mathrm{O}_{2}$ \\
& $50-100$ & $12.22(13.98)$ & - Loss of $4 \mathrm{H}_{2} \mathrm{O}$ \\
{$\left[\mathrm{Co} \mathrm{L}^{2} \mathrm{Cl}_{2}\left(\mathrm{H}_{2} \mathrm{O}\right)_{2}\right] \cdot 4 \mathrm{H}_{2} \mathrm{O}$} & $100-640$ & $35.10(35.72)$ & - Loss of $2 \mathrm{H}_{2} \mathrm{O}, \mathrm{C}_{6} \mathrm{H}_{5}, \mathrm{Cl}_{2}$ \\
& $640-980$ & $34.32(35.74)$ & - Loss of $\mathrm{C}_{11} \mathrm{H}_{6} \mathrm{NO}_{2}$ \\
\hline
\end{tabular}

\subsubsection{Thermal Analysis of 3-thioacetyl-2-amino-1,4-naphthoqunone} (L)-Ni Complex

The thermogram of the complex $\left[\mathrm{NiL}^{1} \mathrm{Cl}_{2}\left(\mathrm{H}_{2} \mathrm{O}\right)_{2}\right] \cdot 4 \mathrm{H}_{2} \mathrm{O}$ displays four stages of decomposition within the temperature range $50^{\circ} \mathrm{C}-980^{\circ} \mathrm{C}$. The first stage between $50^{\circ} \mathrm{C}-250^{\circ} \mathrm{C}$ corresponds to dehydration process. The experimental mass loss of $16.36 \%$ agrees well with the calculated mass loss of $15.36 \%$. The second decomposition stage occurs in the $250^{\circ} \mathrm{C}-450^{\circ} \mathrm{C}$ range is associated with the burning of the loosely $\mathrm{CH}_{3}$ and two coordinated water molecules. This fact find support from the experimental weight loss value $12.58 \%$ and the calculated mass loss $10.88 \%$. The third stage within the temperature range $450^{\circ} \mathrm{C}-670^{\circ} \mathrm{C}$ corresponding to release of $\mathrm{NH}_{2}$ molecule and $\mathrm{Cl}_{2}$ gas. The further degradation of organic ligand takes place in successive steps within the temperature range $670^{\circ} \mathrm{C}-980^{\circ} \mathrm{C}$. The total experimental mass loss is $80.51 \%$ agree well with the calculated mass loss of $80.65 \%$ and the final product obtained is NiS. All results are shown in Table 4. 


\subsubsection{Thermal Analysis of 2-benzoyl-3-amino-1,4-naphthoqunone ( $\left.\mathrm{L}^{2}\right)$-Co Complex}

The TGA curve for the thermal decomposition process of $\left[\mathrm{CoL}^{2} \mathrm{Cl}_{2}\left(\mathrm{H}_{2} \mathrm{O}\right)_{2}\right] \cdot 4 \mathrm{H}_{2} \mathrm{O}$ metal chelate illustrates the thermal decomposition occurs through three decomposition steps within temperature range $50^{\circ} \mathrm{C}-980^{\circ} \mathrm{C}$. The first step of decomposition occurs within the temperature range $50^{\circ} \mathrm{C}-100^{\circ} \mathrm{C}$ of estimated mass loss $12.22 \%$ (calcd. $=13.98 \%)$. This step may be attributed to the separation of four molecules of water of hydration (mole mass $=72.07 \mathrm{~g}$ ). The second step is followed by loss two coordinated water molecules, $\mathrm{C}_{6} \mathrm{H}_{5}$ group and $\mathrm{Cl}_{2}$ gas, within the temperature range $100^{\circ} \mathrm{C}-640^{\circ} \mathrm{C}$ with mass loss of $35.10 \%$ (calcd. $=35.72 \%$ ), the third step starts at $640^{\circ} \mathrm{C}$ and comes to end at $980^{\circ} \mathrm{C}$ corresponding to mass loss range $34.32 \%$ (calcd. $=35.74 \%$ ) due to decomposition of the remaining organic ligand molecule. The mass losses are in agreement with calculated mass loss based on the obtained data (Table 4). The final residue is quantitatively proved to be cobalt (II) oxide. The total experimental mass loss $81.64 \%$ agrees well with the calculated mass loss of $85.45 \%$.

\section{Biological Activity}

The comparison of biological activity of the free ligands $\left(\mathrm{L}^{1}\right.$ up to $\left.\mathrm{L}^{2}\right)$ and its complexes with the standard disc of Ampicillin (antibacterial $\mathrm{G}^{+}$agent and antibacterial $\mathrm{G}^{-}$agent), Amphotericin $\mathrm{B}$ (antifungal agent), towards the different organisms was carried out. The data are listed in Table 5 and shown in Figure 7 \& Figure 8). The free ligands and its metal chelates were screened against Staphylococcus aureus and Bacillis subtilis $\left(\mathrm{G}^{+}\right)$and Escherichia coli $\left(\mathrm{G}^{-}\right)$bacteria and Candida albicans (fungi) to assess their potential antimicrobial agents.

\subsection{Biological Activity of 3-thioacetyl-2-amino-1,4-naphthoqunone $\left(\mathrm{L}^{1}\right)$}

The biological activity of Ligand (3-thioacetyl-2-amino-1,4-naphthoqunone) $\mathrm{L}^{1}$ and its metal complexes shows higher results than that of the free ligand. But all

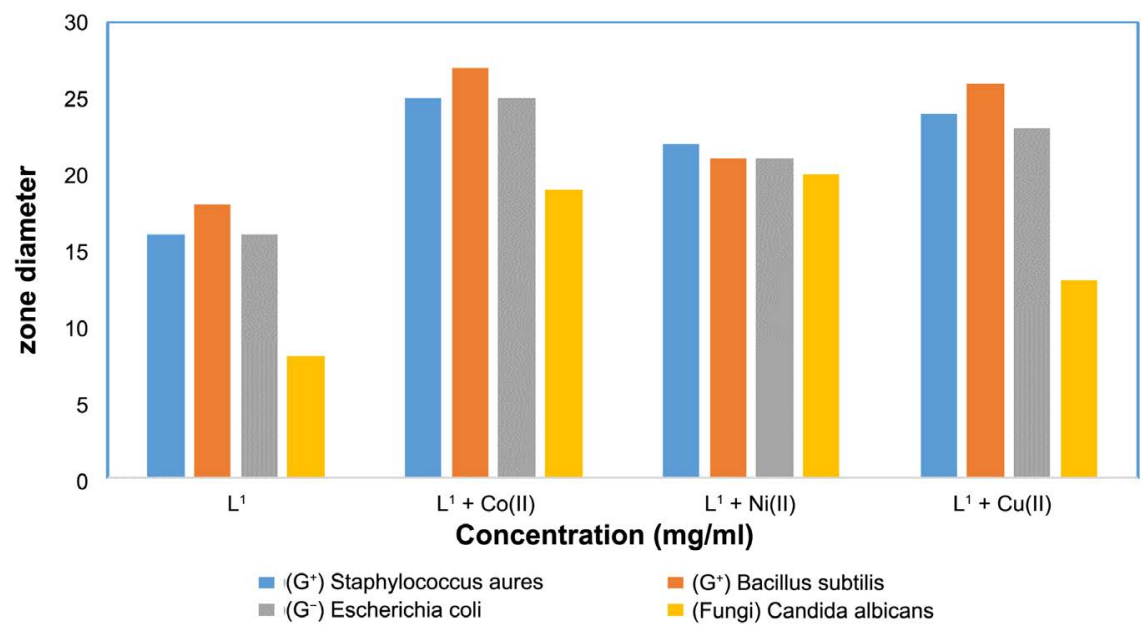

Figure 7. Biological activity of $\left(\mathrm{L}^{1}\right)$ and its metal complexes. 


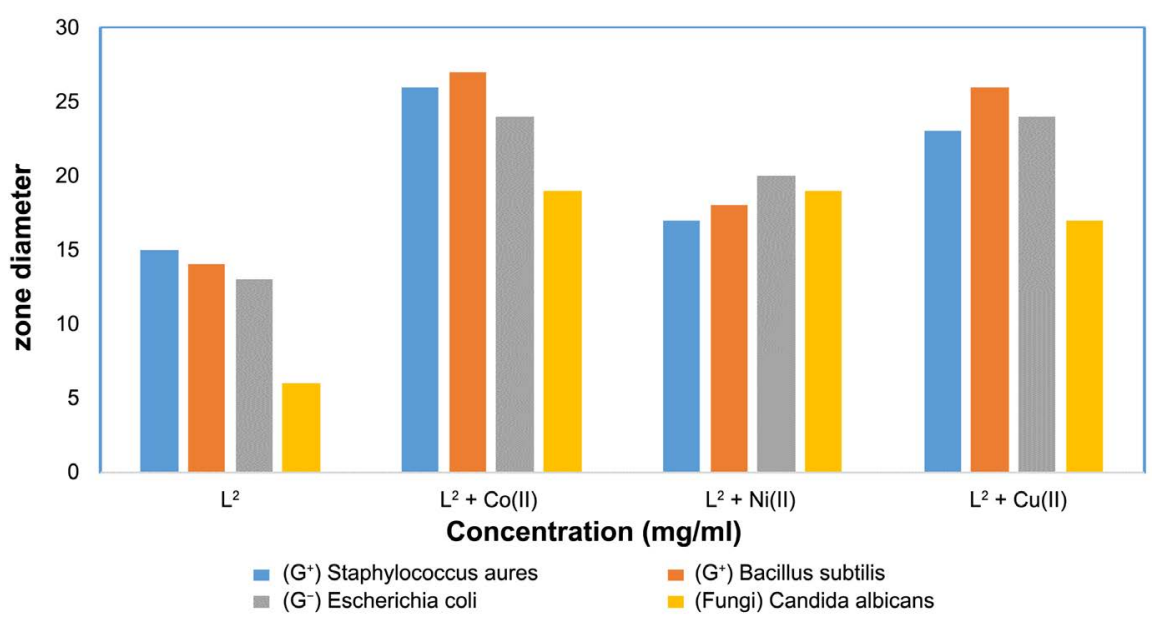

Figure 8. Biological activity of $\left(\mathrm{L}^{2}\right)$ and its metal complexes.

Table 5. Biological activity of $\mathrm{L}^{1}$ and $\mathrm{L}^{2}$ its metal chelates.

\begin{tabular}{ccccc}
\hline \multirow{2}{*}{ Organism sample } & \multicolumn{4}{c}{ Inhibition zone diameter $(\mathrm{mm} / \mathrm{mg}$ sample) } \\
\cline { 2 - 5 } & Staphylococcus aures & Bacillus subtilis & Escherichia coli & Candida albicans \\
\hline $\mathrm{DMSO}$ & 0 & 0 & 0 & 0 \\
$\mathrm{~L}^{1}$ & 16 & 18 & 16 & 8 \\
$\mathrm{~L}^{1}+\mathrm{Co}$ & 25 & 27 & 25 & 19 \\
$\mathrm{~L}^{1}+\mathrm{Ni}$ & 22 & 21 & 21 & 20 \\
$\mathrm{~L}^{1}+\mathrm{Cu}$ & 24 & 26 & 23 & 13 \\
$\mathrm{~L}^{2}$ & 15 & 14 & 13 & 6 \\
$\mathrm{~L}^{2}+\mathrm{Co}$ & 26 & 27 & 25 & 18 \\
$\mathrm{~L}^{2}+\mathrm{Ni}$ & 17 & 18 & 20 & 19 \\
$\mathrm{~L}^{2}+\mathrm{Cu}$ & 23 & 26 & 24 & 17 \\
\hline
\end{tabular}

of them are lower than standard. Therefore, the biological activity of the complexes follows the order $\mathrm{Co}(\mathrm{II})>\mathrm{Cu}$ (II) $>\mathrm{Ni}$ (II) against Staphylococcus aureus, Bacillus subtilis and Escherichia coli organisms. But with Candida albicans the biological activity follows the order $\mathrm{Ni}$ (II) $>\mathrm{Co}$ (II) $>\mathrm{Cu}(\mathrm{II})$.

\subsection{Biological Activity of 2-benzoyl-3-amino-1,4-naphthoqunone $\left(\mathrm{L}^{2}\right)$}

The biological activity of Ligand (2-benzoyl-3-amino-1,4-naphthoqunone) $\mathrm{L}^{2}$ and its metal complexes shows higher results than that of the free ligand. But all of them are lower than standard. Therefore, the biological activity of the complexes follows the order $\mathrm{Co}(\mathrm{II})>\mathrm{Cu}(\mathrm{II})>\mathrm{Ni}(\mathrm{II})$ against Bacillus subtilis and Escherichia coli organisms for $\left(\mathrm{L}^{2}\right)$ and complexes Meanwhile, the biological activity of the complexes follow the order $\mathrm{Co}(\mathrm{II})>\mathrm{Cu}$ (II) $>\mathrm{Ni}$ (II) against Staphylococcus aureus. But with Candida albicans the biological activity follows the order $\mathrm{Ni}(\mathrm{II})>\mathrm{Co}(\mathrm{II})>\mathrm{Cu}(\mathrm{II})$. 
The importance of this, lies in the fact that these complexes could be applied fairly in the treatment of some common diseases caused by E. coli e.g. Septicemia, Gastroenteritis, Urinary tract infections and hospital acquired infections according to [23]. However, the complexes were specialized in inhibiting Gram-positive and Gram-negative bacterial strains. The importance of this unique property of the investigated complexes lies in the fact that, it could be applied safely in the treatment of infections caused by any of these particular strains. Generally, the activity of the free ligand was increased upon complexation with metal ions; the enhancement in activity can be explained on the basis of chelation theory, reported by [24] [25]. Chelation reduces the polarity of the metal ion considerably, mainly because of the partial sharing of its positive charge with donor groups and the possible $\mathrm{p}$ electron delocalization over the whole chelate ring. Chelation not only reduces the polarity of metal ion, but also increases the lipophilic character of the chelate. As a result of this, the interaction between the metal ion and the cell walls is favored, resulting in interference with normal cell processes.

\section{Conclusion}

In the present study, the free ligands $\left(\mathrm{L}^{1}, \mathrm{~L}^{2}\right)$ and its metal complexes $\mathrm{Co}(\mathrm{II})$, $\mathrm{Ni}(\mathrm{II})$ and $\mathrm{Cu}(\mathrm{II})$ respectively were prepared and structurally identified. The structures of free ligands and its metal chelates are proved by elemental analyses and applying spectroscopic measurements (FT-IR, H-NMR, and mass spectra) and confirmed by thermal analyses. The synthesized free ligand is found to be biologically active and their metal complexes showed significantly enhanced antibacterial and antifungal activities against microbial strains in comparison to the free ligand. We are noticed that 1,4-naphthoquinones ligands and its metal chelates are useful tools for the understanding of the antimicrobial mechanism of 1,4-naphthoquinones on these bacteria that will encourage us to continue in this trend.

\section{Conflicts of Interest}

The authors declare that they have no conflict of interest.

\section{References}

[1] Thomson R.H. (1987) Naturally Occurring Quinones. 3rd Edition, Chapman and Hall, London, New York.

[2] Didry, N., Pinkas, M. and Dubreil, L. (1986) Activite antibacterienne de naphthoquinones d'origine vegetale. Annaies Pharmaceutiques Frangaises, 44, 73-78.

[3] Phelps, D.C., Nemec, S., Baker, R. and Mansel, R. (1990) Immunoassay for Naphthazarin Phytotoxin Produced by Fusarium solani. Phytopathology, 80, 298-302. https://doi.org/10.1094/Phyto-80-298

[4] Papageorgiou, V.P., Assimopoulou, A.N., Couladouros, E.A., Hepworth, D. and Nicolaou, K.C. (1999) The Chemistry and Biology of Alkannin, Shikcnin, and Related Naphthazarin Natural Products. Angewandte Chemie International Edition, 
38, 270-301.

https://doi.org/10.1002/(SICI)1521-3773(19990201)38:3<270::AID-ANIE270>3.0.C

$\underline{\mathrm{O} ; 2-0}$

[5] Bakola-Christianopoulou, M.N., Ecateriniadou, L.B. and Sarris, K.J. (1986) Evaluation of the Antimicrobial Activity of a New Series of Hydrcxy-Quinone Chelates of Some Transition Metals. European Journal of Medicinal Chemistry, 21, 385-390.

[6] Joshi, C.R. (1986) Metal Cheiates of Juglones and Their Antimicrobial Activity. Indian Journal of Pharmaceutical Sciences, 48, 101-104.

[7] Chopra, I., Hawkey, P.M. and Hinton, M. (1992) Tetracyclines, Molecular and Clinical Aspects. Journal of Antimicrobial Chemotherapy, 29, 245-277.

https://doi.org/10.1093/jac/29.3.245

[8] Kraken, M. and Wiedemann, B. (1988) Development of Resistance to Nalidixic Acid and the Fluoroquinolones after Introduction of Norfloxacin and Ofloxacin. Antimicrobial Agents and Chemotherapy, 32, 1285-1288. https://doi.org/10.1128/AAC.32.8.1285

[9] Bhavani, S.M. and Bellow, C.H. (2000) New Agents for Gram-Positive Bacteria. Current Opinion in Microbiology, 3, 528-534.

https://doi.org/10.1016/S1369-5274(00)00134-X

[10] Papageorgiou, V.P., Assimopoulou, A.N., Couladouros, E.A., Hepworth, D. and Nicolaou, K.C. (1999) The Chemistry and Biology of Alkannin, Shikcnin, and Related Naphthazarin Natural Products. Angewandte Chemie International Edition, 38, 270-301.

https://doi.org/10.1002/(SICI)1521-3773(19990201)38:3<270::AID-ANIE270>3.0.C $\underline{\mathrm{O} ; 2-0}$

[11] Bogdanov, P.M., Albesa, I., Sperandeo, N.R., Luna, C. and De Bertoreilo, M.M. (1996) Antibacterial Effect of 2-Hydroxy- $N$-(3,4-dimethyl-5-isoxazolyl)-1,4-naphthoquinone-4-imine on Staphylococcus aureus. Experientia, 52, 600-604. https://doi.org/10.1007/BF01969737

[12] Hughes, L.M., Lanteri, C.A., O’Neil, M.T., Johnson, J.D., Gribble, G.W. and Trumpower, B.L. (2011) Design of Anti-Parasitic and Anti-Fungal Hydroxy-Naphthoquinones That Are Less Susceptible to Drug Resistance. Molecular and Biochemical Parasitology, 177, 12-19. https://doi.org/10.1016/j.molbiopara.2011.01.002

[13] Solieman, H.A., Koraiem, A.I.M and Mohmoud, N.Y. (2005) Synthesis of 3-Substituted Benzpyrid-4-imino-2-oxime Derivative. Journal of the Chinese chemical society, 52, 119-124. https://doi.org/10.1002/jccs.200500018

[14] Makoto, O., Teijiro, K. and Tumeaki, H. (1998) Organic Colorants, a Hand Book of Selected Dye for Electro Optical Application. Elsevier Science Publishers, Madison.

[15] Bauer, A.W., Kirby, W.M.M, Sherris, J.C. and Turck, M. (1996) Antibiotic Susceptibility Testing by a Standardized Single Disk Method. American Journal of Clinical Pathology, 45, 493-496. https://doi.org/10.1093/ajcp/45.4 ts.493

[16] Pfaller, M.A., Burmeister, L., Bartlett, M.S. and Rinaldi, M.G. (1988) Multicenter Evaluation of Four Methods of Yeast Inoculum Preparation. Journal of Clinical Microbiology, 26, 1437-1441. https://doi.org/10.1128/JCM.26.8.1437-1441.1988

[17] Liebowitz, L.D., Ashbee, H.R., Evans, E.G.V., Chong, Y., Mallatova, N., Zaidi, M., Gibbs, D. and Global Antifungal Surveillance Group (2001) A Two Year Global Evaluation of the Susceptibility of Candida Species to Fluconazole by Disk Diffusion. Diagnostic Microbiology and Infectious Disease, 40, 27-33. https://doi.org/10.1016/S0732-8893(01)00243-7

[18] Matar, M.J., Ostrosky-Zeichner, L., Paetznick, V.L., Rodriguez, J.R., Chen, E. and 
Rex, J.H. (2003) Correlation between E-Test, Disk Diffusion, and Microdilution Methods for Antifungal Susceptibility Testing of Fluconazole and Voriconazole. Antimicrobial Agents and Chemotherapy, 47, 1647-1651. https://doi.org/10.1128/AAC.47.5.1647-1651.2003

[19] Geary, W.J. (1971) The Use of Conductivity Measurements in Organic Solvents for the Characterisation of Coordination Compounds. Coordination Chemistry Reviews, 7, 81-122. https://doi.org/10.1016/S0010-8545(00)80009-0

[20] Pfeiffer, P., Breith, E., Lubbe, E. and Tsumaki, T. (1933) Tricyclische orthokodensierte Nebenvaenzringe. Justus Liebigs Annalen der Chemie, 503, 84-130. https://doi.org/10.1002/jlac.19335030106

[21] Gomaa, M.M. (2001) The Molecular Design and Optical Characterization of Characterization of Some Novel Condensed and Bridge Head Heterocyclic Quinine Dyes. Ph.D. Thesis, South Valley University, Egypt.

[22] Batterham, T.J. (1973) NMR Spectra of Simple Heterocycles. Wiley, New York.

[23] Jawetz, E., Melnick, J.L. and Adelberg, E.A. (1979) Review of Medical Microbiology, 16th Edition, Lang Medical Publications, Los Angeles, CA.

[24] Mohamed, G.G., Omar, M.M. and Ibrahim, A.A. (2010) Preparation, Characterization and Biological Activity of Novel Metal-NNNN Donor Schiff Base Complexes. Spectrochimica Acta Part A: Molecular and Biomolecular Spectroscopy, 75, 678-685. https://doi.org/10.1016/j.saa.2009.11.039

[25] Murukan, B. and Mohanan, K. (2007) Synthesis, Characterization and Antibacterial Properties of Some Trivalent Metal Complexes with [(2-Hydroxy-1-naphthaldehyde)-3-isatin]-bishydrazone. Journal of Enzyme Inhibition and Medicinal Chemistry, 22, 65-70. https://doi.org/10.1080/14756360601027373 